IZA DP No. 9198

Common Law Marriage and Teen Births

Shoshana Grossbard

Victoria Vernon

July 2015

Forschungsinstitut zur Zukunft der Arbeit Institute for the Study of Labor 


\title{
Common Law Marriage and Teen Births
}

\author{
Shoshana Grossbard \\ San Diego State University \\ and IZA \\ Victoria Vernon \\ Empire State College, New York
}
Discussion Paper No. 9198
July 2015

IZA
P.O. Box 7240
53072 Bonn
Germany

Phone: +49-228-3894-0

Fax: +49-228-3894-180

E-mail: iza@iza.org

Any opinions expressed here are those of the author(s) and not those of IZA. Research published in this series may include views on policy, but the institute itself takes no institutional policy positions. The IZA research network is committed to the IZA Guiding Principles of Research Integrity.

The Institute for the Study of Labor (IZA) in Bonn is a local and virtual international research center and a place of communication between science, politics and business. IZA is an independent nonprofit organization supported by Deutsche Post Foundation. The center is associated with the University of Bonn and offers a stimulating research environment through its international network, workshops and conferences, data service, project support, research visits and doctoral program. IZA engages in (i) original and internationally competitive research in all fields of labor economics, (ii) development of policy concepts, and (iii) dissemination of research results and concepts to the interested public.

IZA Discussion Papers often represent preliminary work and are circulated to encourage discussion. Citation of such a paper should account for its provisional character. A revised version may be available directly from the author. 
IZA Discussion Paper No. 9198

July 2015

\section{ABSTRACT}

\section{Common Law Marriage and Teen Births ${ }^{*}$}

Using microdata from Current Population Survey Fertility supplements 1990-2010 we examine whether Common Law Marriage (CLM) laws in the US affect teen birth rates. CLM effects are identified through cross-state and time variation, as four states repealed the law over the period of study. We find that in the states where CLM laws were first available but then repealed the odds that teens would become new mothers increased, with a larger increase among young black teens. When we include dummies for CLM at various times around the timing of the repeal, it turns out that the likelihood of becoming a mother is most affected by availability of CLM between 1 and 4 years prior to the repeal. There is a small negative effect of CLM on older women becoming mothers. To the extent that they reduce teen births CLM laws are socially desirable and worthy of further study.

JEL Classification: J12, J13, K36

Keywords: fertility, Common-Law marriage, teens

Corresponding author:

Shoshana Grossbard

Department of Economics

San Diego State University

San Diego, CA 92182-4485

USA

E-mail: shosh@mail.sdsu.edu

\footnotetext{
* We thank participants in the Demography seminar at the University of Chicago (especially Ioana Marinescu and Ofer Malamud) and in the IZA SOLE Transatlantic Meetings (especially David Neumark) for valuable comments.
} 


\section{Introduction}

In the recent past the U.S. has experienced a dramatic drop in teen birth rates: between 2000 and 2013 the birth rate per 1,000 teens ages 15 to 19 dropped by 44 percent (Martin et al. 2014). However, at 26.5 per thousand the U.S. teen birth rate remains higher than that of other developed countries (United Nations 2013). It is particularly high for black and Hispanic teens (Hamilton et al 2014). Early parenthood is associated with lower educational attainment and increased poverty for mothers (Hoffman et al. 2008) and lower academic performance and more behavioral problems for children (Martinez et al. 2011), including higher rates of teenage pregnancy for daughters (Moore et al. 2014). Consequently, there is great interest in uncovering the factors that contribute to high teen births in the U.S. and a number of programs have been introduced with the goal of reducing these births (Kearney and Levine 2012). In this paper we examine whether a particular type of state laws regulating cohabitation and marriage, namely Common Law Marriage laws, affect teen birth rates. No previous studies have attempted to link these laws to the incidence of teen parenthood.

Previous research found that declining welfare benefits have a statistically discernible negative impact on teen birth rates (Rosenzweig (1999) and Kearney and Levine (2012)). Lower marital prospects encourage non-marital births among women ages 16-23 (Rosenzweig 1999) and teen birth rates drop with expanded access to state-subsidized family planning and weak labor market conditions (Kearney and Levine 2012). Other factors and policies considered by Kearney and Levine--including abstinence education, mandatory sex education, contraception counseling, state children health insurance policy implementation, and total child support expenditures--did not appear to have an impact on teen birth rates. According to Mechoulan (2011) higher rates of black male incarceration are associated with lower odds of non-marital teenage motherhood among young black women. Some of the factors influencing overall birth rates may also affect teen births rates, and research has shown that overall birth rates are negatively affected by house prices (Dettling and Kearney 2011), availability of abortions (Levine et al. 1999), and culture (Fernández and Fogli 2009).

Closest to the focus of our research are studies of the effect of divorce laws on overall fertility. Laws liberalizing divorce have been shown to lead to a reduction in fertility (Stevenson 2007 and Drewianka 2008 in the U.S. and Bellido and Marcen 2014 in Europe). Since pregnant teens are rarely married previous studies of how divorce laws affect non-marital fertility are particularly relevant: Drewianka (2008) and Bellido and Marcen (2014) report that in both the U.S. and Europe the introduction of unilateral divorce laws led to permanent drops in nonmarital fertility (including births to cohabiting couples) while it only led to transitory drops in marital fertility, resulting in an increase in the ratio of marital to non-marital births. Using a sample of close to 20 different legal regimes Ekert-Jaffe and Grossbard (2008) found that the likelihood of an unpartnered birth was lower when a country or province had community property laws guiding division of assets in case of dissolution. However, such laws had less of an impact on the likelihood that a teen had a child while being out-of-couple.

US states with CLM laws offer their heterosexual residents the option of being considered as married by living together and holding themselves out as spouses by calling each other husband and wife in public, using the same last name, filing joint tax returns, or declaring their marriage on applications, leases, birth certificates and other documents. As of 2014 such common-law marriage (CLM) laws were effective in 11 states--Alabama, Colorado, Iowa, Kansas, Montana, New Hampshire (posthumously for purposes of inheritance), Oklahoma, Rhode Island, South Carolina, Texas, and Utah--as well as in the Navajo Nation and the District of Columbia. CLM does not require a ceremony or a license. Once established, CLM is like a regular marriage, and 
it requires an official divorce in case of dissolution. Cohabiting couples who have a child are almost certainly considered married in a CLM state. In CLM states teenagers who started cohabiting below the legal age of marriage (18 in most states) could possibly claim they are married after they turn 18 , especially if they have a child with their partner. ${ }^{1}$

Data availability on CLM is a problem. There is virtually no official data on CLM marriages published by state or local governments, even though some counties encourage residents to register their CLMs. The internet contains a lot of information and legal advice for couples about CLM, so we know it is practiced. An indication of CLM's prevalence is that about one hundred legal CLM-related judgments were issued each decade in each state at the federal level (Lind, 2008). We are assuming that the state residents are familiar with the law.

We analyze micro data on US-born men and women age 15 to 25 from CPS June Fertility Supplements 1990-2010. Over the period covered by our data CLM was abolished by Ohio (1991), Idaho (1996), Georgia (1997), and Pennsylvania (2005), thus providing us with a quasiexperiment when testing effects of CLM laws.

In previous research we found that CLM laws had a negative impact on couple formation: where and when CLM is available men and women ages 18 to 35 were less likely to live in couples (Grossbard and Vernon 2014). Couples are often formed with the purpose of starting a family, and families are often formed as a consequence of unplanned pregnancy. Cohabitation and having a child together is a ground for cohabitants to claim marriage unilaterally according to Common Law Marriage laws. Therefore it is possible that if CLM laws reduce cohabitation they also lower birth rates.

In Section II we expand on the reasons why CLM laws may affect the likelihood that a woman becomes a mother, and how this is likely to vary with teen status, child parity, and ethnicity. The data and methods are presented in Sections III and IV, and results in Section V. We conclude that in the states where CLM laws were first available but then repealed the odds of becoming a new mother among young teens increased, with a larger increase among young black teens. Results for women ages 19 to 21 and 22 and 25 are more mixed. The laws thus seem socially desirable in view of the reduced teen birth rates they appear to be associated with.

\section{CLM Laws, Teen Status and the Likelihood that a Woman is a Mother}

In the tradition of the New Home Economics (NHE) pioneered by Gary Becker (1960) and Jacob Mincer (1963) it is assumed that decisions regarding fertility are a function of costs and benefits. However, most economists analyzing fertility assume that the unit making decisions regarding births is a household. In contrast, in line with Ekert-Jaffe and Grossbard (2008) and Grossbard (2011), we assume that a woman makes that decision and that her decision is potentially tied to the decision on whether to have a child out-of-couple or after first becoming part of a couple.

A decision-making model. Consider a woman deciding on whether to give birth to a child or not. Her decision is related to other decisions, some of which more under her control than others. In the U.S. women tend to have control over whether to engage in sex with or without protection, to have an abortion, or to give their child for adoption. They may also decide on whether to have a child alone $(a)$ or in couple. If in couple, they can chose between entering (non-marital) cohabitation ( $\mathrm{co}$ ) or marriage $(\mathrm{ma}$ ) with a man or a woman. We assume heterosexuality and

\footnotetext{
${ }^{1}$ In Nebraska the legal age of marriage is 19. All states require parental consent for minors age 16-18 and minors age 1415 require permission from Juvenile Court. See www.usmarriagelaws.com/search/united_states/teen_marriage_laws/
} 
denote BR as the benefit to cost ratio of each of the three ways they can bring a child in the world.

There are three periods. In period zero the woman is making the decision regarding having a child in each relationship status that she may enter in period 1. The expected BR at time zero is

(1) $E(B R)=p_{c o} E\left(B R_{c o}\right)+p_{m a} B R_{m a}+p_{a} B R_{a}$, where

$p$ is the probability of each relationship in the first period and where $p_{c o}+p_{m a}+p_{a}=1$. Men's willingness to have a child and/or to form a couple with her will influence the decision. Having and raising a man's child is a form of Work-In-Household (WiHo) that a mother may supply to men (see Grossbard 2015). The potential benefits of being a mother include resources (monetary, in-kind, and caring time) that men are willing to provide their child's mother and that can be interpreted as payments for WiHo. As in Mincy, Grossbard and Huang (2005) women having children out-of-couple (as lone mothers) may also obtain some resources from the child's father; but fathers are expected to offer more benefits to mother and child if there is cohabitation, and even more if the couple is married. The higher the BR for cohabiting and married women relative to that for women living alone the more women are likely to give birth while being in couple rather than alone (Ekert-Jaffe and Grossbard 2008). ${ }^{2}$

Conditions in markets for WiHo supplied in cohabitation or marriage are given to the woman, influencing (1) the probabilities $p_{c o}$ and $p_{m a}$ and (2) the ratio of estimated benefits to costs of being a mother in each couple form $B R_{c o}$ and $B R_{m a}$.

In period 2 it is assumed that (a) only one relationship switch is feasible: switching from cohabitation to marriage, and (b) BR varies depending on who initiates a switch from cohabitation to marriage. In equation 1 we included the expected benefit to cost ratio of becoming a cohabiting mother in period $1, E\left(B R_{c o}\right)$, taking into account three possibilities in period 2: staying in cohabitation ( $\mathrm{COCO}$ ), a switch to marriage preferred by the woman, possibly in conjunction with the man, (comaf), and a switch to marriage preferred by the man, comam. $E\left(B R_{c o}\right)$ thus equals:

(2) $E\left(B R_{\text {co }}\right)=p_{\text {coco }} B R_{\text {co }}+p_{\text {comaf }} B R_{\text {comaf }}+p_{\text {comam }} B R_{\text {comam }}$

Replacing $p_{\text {coco }}$ with $\left[\left(1-p_{\text {comaf }}-p_{\text {comam }}\right)\right.$ and $E\left(B R_{c o}\right)$ in equation 1 with equation 2 we obtain that at time 0 a woman's expected benefit to cost ratio of having a child is:

(3) $E(B R)=p_{c o}\left[\left(1-p_{\text {comaf }}-p_{\text {comam }}\right) B R_{c o}+p_{\text {comaf }} B R_{\text {comaf }}+p_{\text {comam }}\right.$ $\left.B R_{\text {comam }}\right]+p_{m a} B R_{m a}+p_{a} B R_{a}$

\footnotetext{
${ }^{2}$ Another law that could affect fertility via its effect on men's willingness to cohabit or marry is a law establishing unilateral divorce. Such law is likely to increase a single man's willingness to marry his unborn child's mother. In turn, a higher likelihood of marriage will make it more likely that a woman will choose marital fertility rather than its alternatives (no birth or non-marital fertility). This helps explain the finding that unilateral divorce laws led to a drop in the ratio of non-marital to marital births in the U.S. (Drewianka 2008) and Europe (Bellido and Marcen 2014). Drewianka's explanation for this finding was similar: unilateral divorce leads to lower costs of entering marriage.
} 
The more men are willing to pay for women's mothering WiHo the higher the various Benefit to Cost ratios BR and the more a woman is likely to give birth.

Our focus is on the expected effect of CLM on the expected BR from becoming a mother. Accordingly, we differentiate equation 3 according to CLM and obtain:

(4) $\partial E(B R) / \partial C L M=p_{c o}\left(\partial p_{\text {comaf }} / \partial C L M\right)\left(B R_{\text {comaf }}-B R_{c o}\right)$

$+p_{c o}\left(\partial p_{\text {comam }} / \partial C L M\right)\left(B R_{\text {comam }}-B R_{c o}\right)$

$+\left(\partial p_{c o} / \partial C L M\right)\left[E\left(B R_{c o}\right)-B R_{m a}-B R_{a}\right]$

The predicted effect of CLM on the BR of becoming a mother, and therefore the likelihood of giving birth, is composed of three terms. The first two terms include effects of CLM on the probability that someone will initiate a switch from cohabitation to marriage in period 2: these terms are expected to be positive since CLM laws make it easier to make such switches.

$\mathrm{a}$ / the first term is expected to be positive: it contains the positive effect of CLM on $p_{\text {comaf }}$, a woman's preferred transition from cohabitation to marriage, and the difference between BR in a preferred state and a less preferred state (also a positive term).

$\mathrm{b}$ / the second term is expected to be negative because the partial effect of CLM on a man's preferred transition from cohabitation to marriage is positive and from a woman's perspective $\left(B R_{\text {comam }}-B R_{\text {co }}\right)$ is negative.

C/ The third term includes the partial effect of CLM on $p_{c o}$, the probability of cohabitation in the first period. This partial effect is expected to be negative to the extent that when CLM laws are applied there is potentially more to loose from cohabitation for men and women with expected incomes exceeding those of their partners. The term in square brackets is expected to be positive.

To the extent that terms b/ and c/ are negative as expected, and their absolute value exceeds that of positive term a/, the net effect of CLM on a woman's expected benefit to cost ratio of becoming a mother will be negative and CLM will be associated with fewer women becoming mothers.

Assuming that terms $\mathrm{b} /$ and $\mathrm{c} /$ dominate, it follows that:

Prediction 1. The availability of a CLM law reduces the likelihood that a woman gives birth.

Teens under 18. Teens typically live with their parents, especially if they are younger than 18 and are not allowed to marry without parental consent (In all the states where CLM laws changed in the period under investigation that legal age for marriage was 18. $)^{3}$ Therefore, in all legal regimes with a minimum age at marriage requirement, and relative to the marriage probability, women younger than 18 have a higher probability of cohabitation $p_{c o}$ in period 1 than women 18 or older. CLM in the case of these under-age women may have a larger negative effect on $p_{c o}$ and thus negative term c/ may be larger. Therefore,

Prediction 2. CLM laws ruling the transition from cohabitation to marriage are more likely to have a negative effect on adolescent women's likelihood of becoming a mother than on that of older women.

\footnotetext{
${ }^{3}$ The costs of cohabitation are also higher for individuals 18 or younger to the extent that education is compulsory until age 18 and parenthood interferes with high school completion.
} 
Women pregnant with their first child or considering conceiving their first child are more likely to live apart from their child's father than women who already have children. This is another case where there is a higher probability of choosing cohabitation in period 1 . It follows that

Prediction 3. The discouraging effect of CLM laws on the likelihood that women become first-time mothers is expected to be larger than these laws' effect on the likelihood that mothers have additional children.

The more prevalent non-marital cohabitation in a particular group, i.e. the larger $p_{c o}$ in equation 4 for members of that group, the larger the predicted effect of CLM laws on the expected benefits to cost ratio of becoming a mother. Among blacks non-marital cohabitation is more common than among whites: among all couples living together, 17\% are unmarried among blacks and 11\% unmarried among whites (Vespa, Lewis and Keider 2013); Grossbard and Vernon (2014) find that relative to black women white women are twice as likely to be in couple. Therefore

Prediction 4. Relative to their impact on white women CLM laws are expected to have more impact on the likelihood that black women become mothers.

This black/white differential could also vary with how easy it is for black and white mothers to find adoptive parents for their child in case they prefer giving the child up for adoption.

\section{Data and Sample Means}

We analyze data on teen childbearing using microdata from the June Fertility Supplements to the Current Population Surveys ${ }^{4}$ (CPS) This supplement is administered approximately every two years and is available for the years 1990, 1992, 1994, 1995, 1998, 2000, 2002, 2004, 2006, 2008, and 2010. The period covered spans the years during which 4 states abolished CLM: Ohio (October 1991), Idaho (1996), Georgia (1997), Pennsylvania (2005). We considered using CDC Vital Statistics data available yearly for the period 1988-2012. ${ }^{5}$ However the Vital Statistics are state level data that group new births and allow us to calculate birth rates per 1,000 women. Some rates can be calculated for ages 15, 16, 17, 18, and 19 but some are only available for the following age categories: ages 15-17, ages 15-19, ages 20-44. Given the great heterogeneity in probability of using CLM, some of which is illustrated below, we find it crucial to apply our models to individual data rather than to state-level data only available for broad age categories or categories that don't suit our needs (such as the distinction between teens below and above the legal age for marriage). We therefore decided to solely base our analyses on individual data collected in the CPS.

CPS and its June extracts are large nationally representative datasets that contain information on demographic characteristics of all family members, mother's age, number of children per woman and year and month of birth of the last child. One drawback of this supplement is that household income information is not available. We overcome this problem by including into our regressions the highest education level among household members for the youngest group of women age 15-18 who are likely to live with their families. In regressions for older women we

\footnotetext{
${ }^{4}$ https://cps.ipums.org/cps/

${ }^{5}$ http://www.cdc.gov/nchs/products/nvsr.htm and http://www.cdc.gov/nchs/products/mvsr.htm
} 
rely on women's own education level indicators to approximate their income. Another drawback of CPS is that not all cohabiting couples can be identified prior to 2007. Before that year only relationships between household heads and their partners were recorded while other household members were assigned either married or single status, and before 1995 cohabiting partners were pooled with roommates. This precludes our analysis of partnered relationships among teen mothers.

We select women age $15-21, N=71,030$, with $4500-5000$ records per year. The sample includes 42,106 adolescent girls age 15-18. Around 21-25\% of the sample lives in CLM states in various years. Sample means are presented in Table 1. CLM states have a higher share of Hispanic teens, lower share of foreign-born. More of them live in central cities and come from less educated families. It can be seen that a higher share of teens in CLM states are mothers, a higher share of girls from CLM states had a child within the last calendar year. They are more likely to be married and to have been married before. Most differences by CLM status are statistically significant at $5 \%$. About $5 \%$ of our sample is foreign-born, and we expect the foreign-born to be less aware of CLM laws than the natives. However, the information on country of birth is only available starting in 1994, which implies that if had we restricted our sample to natives we would have lost data for the years 1990 and 1992 . We therefore present results for a sample including foreign-born respondents. Results don't change much when we exclude the foreign-born.

Figure 1, Panel A, shows the share of girls ages 15-18 who became mothers in the 12 months prior to the survey, by ethnicity and CLM availability. The percentage is the highest, $10.8 \%$, among Hispanic girls in CLM states and the lowest among non-Hispanic white girls in non-CLM states, 4.2\%. Panel B shows similar statistics for girls ages 15-18 who became first-time mothers. The proportion of black girls in became first-time mothers in CLM states is considerably lower than that proportion in non-CLM states (2.2\% versus $4.1 \%)$. Remarkably, while that proportion is almost the same for white and black teens ages 15-18 in CLM states it is almost 2.5 times higher for black young teens in non-CLM states than for their white counterparts.

Figure 2 shows trends in motherhood among women 15 to 18 for the four transition states. For each transition state we are considering up to 7 years prior to the repeal and up to 13 years after the repeal. No striking regularities are noticeable. The fact that data are only available (roughly) every two years helps explain the patterns.

\section{Empirical Strategy}

Our empirical strategy is to use the individual-level CPS data to estimate a series of models where $Y$, the outcome of interest, is a function of CLM and other determinants of a decision. For individual $i$ from state $s$ in year $t$, outcome $Y$ is:

$$
\text { (5) } \mathrm{Y}_{\mathrm{ist}}=\alpha \mathrm{CLM}_{\mathrm{st}-1}+\beta \mathrm{X}_{\mathrm{ist}}++\beta \mathrm{Z}_{\mathrm{ist}-1}+\delta_{\mathrm{s}}+\gamma_{\mathrm{t}}+\mathrm{u}_{\mathrm{ist}}
$$

where $Y$ is principally the probability that a woman had her first child in the last 12 months, i.e. that she is a first-time mother. We also estimate some regressions with $Y$ defined as the probability that a woman had any child (first or next) in the last 12 months, for the purpose of comparison.

CLM, our variable of interest, indicates whether the state of residence recognized CLM in the previous year when the woman got pregnant; $(t-1)$ stands for previous year, 6 -18 month prior to the survey administered in June. Identification of a CLM effect arises through cross-state variation and variation over time as four states repealed CLM over the period examined. If the availability of CLM increases fertility, all other state and individual characteristics held constant, 
we will observe a positive coefficient $\alpha$ in the equation for the probability of being a (new) mother. If CLM reduces the odds of becoming a mother, the corresponding coefficients will be negative.

$\delta_{\mathrm{s}}$ are state fixed effects to account for unobservable differences in economic, legal, demographic and cultural environment that may affect individual choices, such as laws regarding child custody, state abortion policies and religiosity;

$\gamma_{\mathrm{t}}$ are time dummies to capture the time trend; and

$\mathrm{u}_{\mathrm{ijt}}$ are i.i.d. error terms.

The vector of individual demographic controls $X$ consists of age dummies, dummies for black, Hispanic, Asian and other ethnicity, two indicators for metropolitan residence (central city and outside central city with non-metropolitan with non-identifiable as a reference group), and indicators for whether the respondent completed high school, some college or college degree (the youngest group excludes college degree dummies). In regressions for the youngest respondents we also include 3 dummies for the highest educational level in the household (no high school, college and graduate degree, with high school as a reference group) as a proxy for the missing incomes.

The vector of state-level controls $Z$ include sex ratios calculated by respondents' age and ethnicity to reflect that most couples are formed between people of the same ethnicity, unemployment rate to account for economic conditions that may have had an impact on couple formation; log of median household income to capture aggregate economic conditions and the cost of living, the shares of black and Hispanic population, the share of adult population with a college degree and the log of maximum TANF benefits for a family of two as a proxy for welfare support for single mothers. State-level controls are from the year before $(t-1)$ to match the timing when the birth decision was made by most women. Variable definitions and mean values are reported in Tables 1 and $2 .^{6}$

In some versions of this model we also include interactions between CLM and black and CLM and Hispanic as well as three indicators for the two years immediately before the repeal of the law, 3-4 years before the repeal and two years after the repeal in transition states in order to examine whether anticipation of the law changes or the aftermath of the changes affect behavior.

(6) $\mathrm{Y}_{\mathrm{ist}}=\alpha 1 \mathrm{CLM}_{\mathrm{st}-1}+\alpha 2 \mathrm{~T}_{\mathrm{st}-2}+\alpha 3 \mathrm{~T}_{\mathrm{st}-4}+\alpha 4 \mathrm{~T}_{\mathrm{st}+2}+\alpha 5 \mathrm{CLM}_{\mathrm{st}-1} *$ Black + $\alpha 6 \mathrm{CLM}_{\mathrm{st}-1} *$ Hisp $+\beta \mathrm{X}_{\mathrm{ist}}+\delta_{\mathrm{s}}+\gamma_{\mathrm{t}}+\mathrm{u}_{\mathrm{ist}}$

Ideally, we would have liked to also present separate results for blacks, Hispanics, and whites given that most adult couples - and conceivably teen couples are well - are within the same race. There are reasons to believe that marriage market conditions differ by ethnicity in our data: means and standard deviations of the dependent variables are significantly different for the white and black subsamples. However sample sizes of non-white groups are not sufficiently large for race-specific difference-in-difference analyses.

We estimate these probabilities for two samples of teenage women --the very young age 1518, and older teens age 19-21-- as well as for women ages 22-25.

\footnotetext{
${ }^{6}$ We have also tried including the following control variables: shares of black and Hispanic population, housing price index, the fraction of State House that is Democrat, the number of abortion providers per 100,000 females, and the number of male prisoners per 100,000 male population. None of these variables have a significant effect on the probability that the adolescent has a child with the exception of the male imprisonment rate which has a negative weakly significant impact. The same variable however has a positive impact on teen fertility at the state level, possibly because it is correlated with other risky behavior of teens.
} 
Several probit models are estimated with various sets of controls, state and year fixed effects, and with state-specific time trends. We also estimate linear probability models and the results are similar. We choose to only report probit models.

Standard errors are clustered by state/year to adjust for correlated standard errors that are likely to arise due to common random effects at the state-year level. This is a necessary step because the unit of observation is at the individual-level while the variation is at the state-level (Moulton 1990).

\section{Results}

Table 3 shows estimates of the marginal effects of CLM and other variables of interest on the likelihood that women age 15-18 became mothers in the last twelve months. These probit marginal effects show how much the probability of the outcome variable changes when the value of CLM changes from zero to one, holding other variables at their means. Panel A is for firsttime mothers and Panel B for mothers of children of any parity. Models in columns 1 and 2 include only CLM, model 3 includes the before and after dummies, models 4 and 5 add state characteristics and the interactions between CLM and black and CLM and Hispanic. Models 6 and 7 reproduce the results in columns 1 and 4 using only data from four transition states. All models include individual characteristics and either state and year fixed effects or state-specific linear trends.

The full list of controls in vector $\mathrm{X}$ can be found in the Appendix where we show full estimates of models 4 and 5 for the probability that adolescents had their first child in the 12 months prior to the survey.

The results in the first row and the first two columns of Table 3A indicate that coefficients of CLM in regressions of first time motherhood among the youngest women age 15-18 are negative and statistically significant at the 1\% level, suggesting that everything else held constant, including state-specific characteristics, CLM is associated with lower rates of fertility among these young teens.

Columns 3 to 5 present estimates of the model with indicators for the years before and after abolition of the law in transition states, as specified in equation 6. The coefficient on CLM is now insignificant, but the coefficient on the indicator for 3-4 years immediately before the repeal of the law is significant and negative implying that chances that a teen girl gets pregnant and decides to keep the child are significantly lower 3-4 years before to the law's repeal. The coefficients on the indicator for 1-2 years before repeal are also negative but only significant at conventional 5\% levels and only in the regression for transition states. The coefficients on the years immediately after the abolition of CLM in transition states are not significantly different from zero, indicating that past presence of CLM does not influence women's fertility choices at present. Models 6 and 7 for transition states reaffirm the pattern found in the full sample: when only CLM the year before is included it has a negative effect on young teens' probability of becoming mothers, but that after accounting for the years prior and following the repeal, 3-4 years before the repeal is when first time pregnancies are the least likely to occur. Model 7 also suggests that there may be negative effects of 1 or 2 years before and after the repeal.

Panel B in Table 3 indicates that most of these findings also extend to the likelihood that young teens become mothers either for the first time or at higher parity. While CLM is associated negatively with the probability of young teens giving birth, the effect is focused on the two years preceding the abolition of the law. 
In most regressions in Table 3 that include the interaction between CLM and Black it has a negative sign. In contrast we don't find significant differences in the effect of CLM on Hispanics and non-Hispanic whites.

Table 4 compares the results in columns 4 and 5 of Table 3 (for young teens ages 15 to 18) to results of similar regressions for two groups of older women: women 19 to 21 and 22 to 25 . All significant CLM effects on younger teens are negative, but in the case of women older than 18 some of the CLM coefficients are positive. This is consistent with CLM causing more of a drop in fathers' willingness to cohabit with pregnant women younger than 18 relative to their willingness to cohabit with pregnant women older than 18. The positive coefficients of CLM 1-2 years before repeal, for women 19 to 25 having any child (Panel B), are consistent with CLM encouraging these women to request unilateral marriage to their own advantage.

Summary of results in light of predictions in Section II. Many of our regressions indicate that when CLM laws apply women are less likely to give birth. Consistent with prediction 2 we find negative CLM effects on birth probabilities of young teens ages 15 to 18 more so than for older teens ages 19 to 21 or women ages 22 to 25. For women above age 18 CLM effects are sometimes positive. We expected negative CLM effects to be stronger for first-time mothers than for all mothers (prediction 3) but that prediction does not get much support. As for prediction 4 - stronger negative effects of CLM for blacks than for whites-it only gets support for young teens.

Robustness checks. Our results are robust to various changes in specification. We experimented with excluding New Hampshire, where CLM is available only in case of a partner's death, and Nebraska, where marriage age is 19 which is different from age 18 in other states. We also ran regressions in which we included foreign born women who may be less likely to be familiar with US laws but by doing so we increase the sample. Yet our main results are not sensitive to these changes. We also repeat out analysis using a different time frame: we estimate the probability that a woman had a child in the last 18 months. The results are very similar.

The difference-in-difference (DD) approach that we used for identification has been shown to suffer from a serial correlation problem. As a result, the standard errors of DD estimators are often underestimated and thus the statistical significance of the coefficients is overestimated. Following Bertrand, Duflo, and Mullainathan (2004), we attempt to deal with possible serial correlation of errors by estimating a panel data model using individual-level data aggregated by year/state cells. We compute these estimates and record the results in Table 5. First, we regress the binary birth data on personal characteristics. Then we calculate means of residuals by year/state and regress the mean of residuals on CLM, state characteristics, and state and year fixed effects. The coefficients of the linear probability models are of similar sign but less strong than the individual-level results.

\section{Conclusions}

We analyzed whether the likelihood that women--including teens--became mothers over the last 12 months is linked to whether Common Law Marriage laws were effective in the state at the time of pregnancy. Our analyses of CPS data reveal that births to young teens age 15 to 18 were negatively affected by these laws: where and when the laws applied teens were significantly less likely to give birth, especially if they were black. This applied to both all births and first births. When we include dummies for CLM at various times around the timing of the repeal, it turns out that the likelihood of being a mother is most affected by availability of CLM between 1 and 4 years prior to the repeal. Effects of CLM on the likelihood that slightly older women, ages 19 to 
21 and 22 to 25, become mothers are also often significantly different from zero but not as consistently negative.

These findings are consistent with our predictions based on a model of women as independent decision-makers influenced by costs and benefits of having a child under various legal regimes and also influenced by how CLM is likely to affect men's willingness to cohabit and to switch from cohabitation to marriage. We also predicted stronger negative effects for blacks than for whites, and found this to be the case for women age 15 to 18 .

The finding that when CLM laws were effective young teens were less likely to become mothers implies that the repeal of CLM laws led to higher teen fertility. It follows that this repeal in four states does not explain the observed trend towards lower birth rates among teens. Nevertheless, should our finding be confirmed by further research it implies that CLM laws prevent births to very young teens ages 15 to 18, and therefore from this perspective should remain effective or reinstated where they were abolished. However, CLM laws also appear to delay gender convergence in labor supply (Grossbard and Vernon 2015) and to discourage couple formation among women at the conventional age of childbearing (ages 18 to 35, Grossbard and Vernon 2014). Whether the repeal of CLM laws is desirable should be carefully assessed based on further research and consideration of a variety of consequences that these laws seem to have on observed outcomes. 


\section{References}

Becker, G. S. (1960), "An Economic Analysis of Fertility." In Demographic and Economic Change in Developed Countries, a Conference of the Universities--National Bureau Committee for Economic Research. Princeton, N.J.: Princeton University Press.

Bellido, H. and M. Marcen (2014), “Divorce Laws and Fertility”, Labour Economics 27:56-70.

Bertrand, M., Duflo, E., and S. Mullainathan (2004), "How much should we trust difference-indifference estimates?” The Quarterly Journal of Economics 119(1):249-275.

Dettling, L., and M. Kearney (2011), “House Prices and Birth Rates: The Impact of the Real Estate Market on the Decision to Have a Baby”, NBER working paper 17485

Drewianka, S. (2008), “Divorce Law and Family Formation”, J of Population Economics 21:485-503.

Ekert-Jaffe, O., and S. Grossbard (2008), “Does Community Property Discourage Unpartnered Births?” European J of Political Economy 24(1):25-40.

Fernández, R. and A. Fogli (2009), “Culture: An Empirical Investigation of Beliefs, Work, and Fertility” American Economic Journal: Macroeconomics 1(1):146-77.

Grossbard, S. (2011), “Independent individual decision-makers in household models and the New Home Economics” in Household Economic Behaviors edited by J. Alberto Molina. New York: Springer.

Grossbard, S. (2015), The Marriage Motive. New York: Springer.

Grossbard, S. and V. Vernon (2014), “Common Law Marriage and Couple Formation” IZA Journal of Labor Economics 3:16.

(2015), Convergence in male-female labor supply and common law marriage”, Research in Labor Economics, Volume on Gender Convergence in the Labor Market, 41: 143-175.

Hamilton, B. E., Martin, J. A., Osterman, M. J. K., \& Curtin, S. C. (2014). "Births: Preliminary data for 2013. Hyattsville, MD: National Center for Health Statistics. Retrieved August 20, 2014, from http://www.cdc.gov/nchs/data/nvsr/nvsr63/nvsr63_02.pdf

Hoffman, S. D. and Maynard, R. A. (Eds.). (2008). Kids having kids: economic costs and social consequences of teen pregnancy (2nd ed.). Washington, DC: Urban Institute Press.

Kearney, M. and P. B. Levine (2012). “Explaining Recent Trends in the U.S. Teen Birth Rate”, NBER working paper 17964.

Levine, P. B., D. Staiger,, T. J. Kane, and D. J. Zimmerman (1999). "Roe v Wade and American fertility”. Am J Public Health. February; 89(2): 199-203. 
Lind, Goran. (2008). Common Law Marriage: a Legal Institution for Cohabitation. New York: Oxford University Press.

Martin, J. A., Hamilton, B. E., \& M. J. K. Osterman (2014). “Births in the United States”, 2013. Hyattsville, MD.

Martinez, G., Copen, C. E., \& Abma, J. C. (2011). “Teenagers in the United States: sexual activity, contraceptive use, and childbearing, 2006-2010 National Survey of Family Growth.” Washington, DC: National Center for Health Statistics. Retrieved August 6, 2014, from http://www.cdc.gov/nchs/data/series/sr_23/sr23_031.pdf

Mechoulan, S. (2011), “The External Effects of Black Male Incarceration on Black Females”, Journal of Labor Economics, Vol. 29, No. 1 (January), pp. 1-35

Mincer, J. (1963), "Market Prices, Opportunity Costs, and Income Effects," in C. Christ (ed.) Measurement in Economics. Stanford, CA: Stanford University Press.

Mincy, R., S. Grossbard and C. Huang "An Economic Analysis of Co-Parenting Choices: Single Parent, Visiting Father, Cohabitation, Marriage”, EconWPA papers in Labor and Demography \#0505004, May 2005.

Moore, K., Sacks, V., Manlove, J., \& I. Sawhill, I. (2014), “What if” you earned a diploma and delayed parenthood?” Bethesda, MD: Child Trends. Retrieved August 20, 2014, from http://www.childtrends.org/wp-content/uploads/2014/12/201427SocialGenomeDelayChildbearing.pdf

Rosenzweig, M. (1999), “Welfare, Marital prospects, and Nonmarital Childbaring”, The Journal of Political Economy 107(6, Part 2): S3-S32.

Stevenson, B. (2007), “The Impact of Divorce Laws on Marriage: Specific Capital”, Journal of Labor Economics 25:75-94.

United Nations (2013). 2012 Demographic yearbook. New York, New York. Retrieved September 2014, from

http://unstats.un.org/unsd/demographic/products/dyb/dybsets/2012.pdf

Vespa, J., J. M. Lewis, and R. M. Kreider. “America’s Families and Living Arrangements 2012”, August 2013. Available at https://www.census.gov/prod/2013pubs/p20-570.pdf 
Figure 1. Percent of adolescent girls age 15-18 who ever gave birth and those who gave birth for the first time. June CPS 1990-2010.
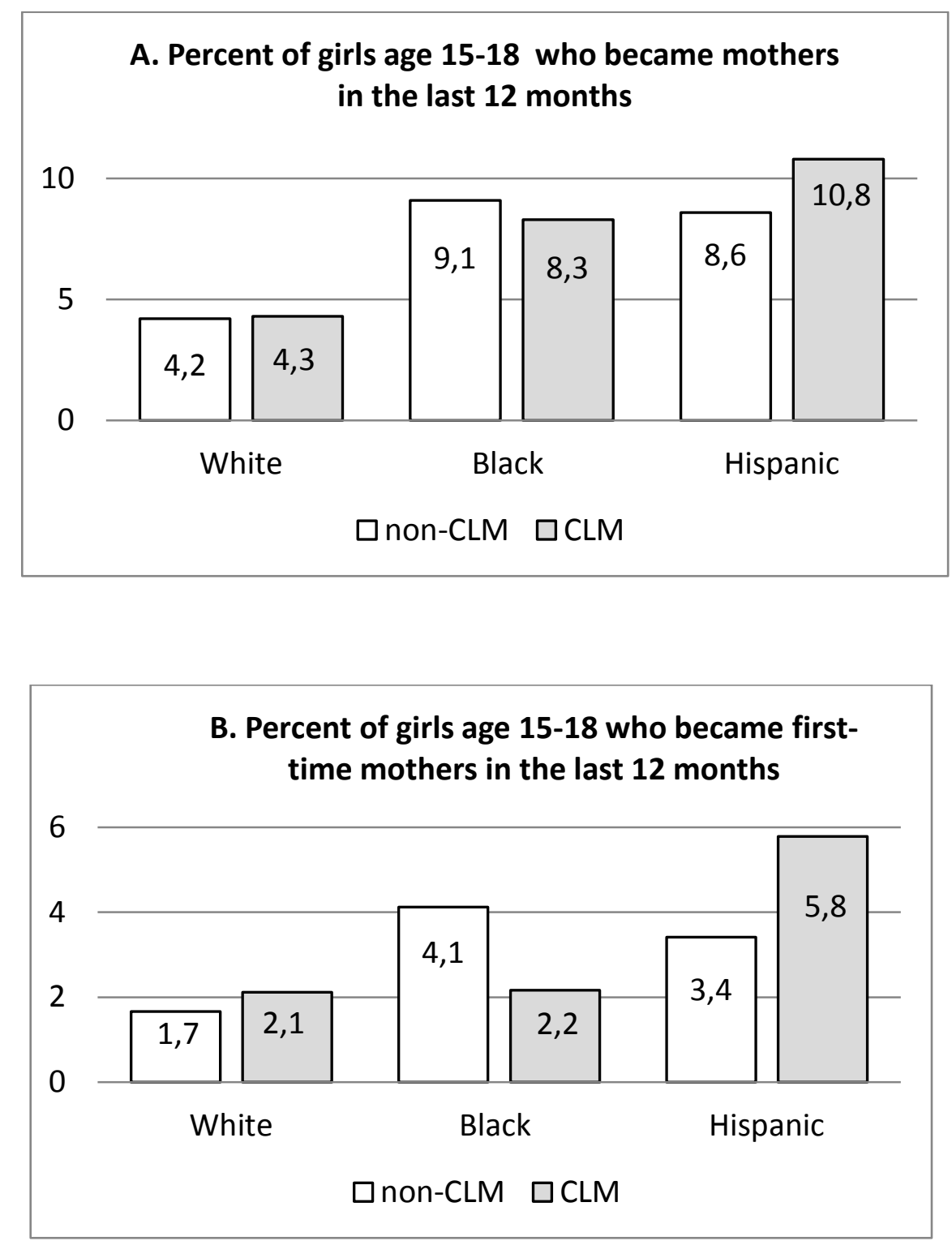

The data is weighted using survey weights. The sample in panel B excludes 1,300 girls who had a child more than 12 months prior to the survey. 
Figure 2. Evolution of motherhood rates for women age 15-18, June CPS individual-level data 1990-2010. Transition states.

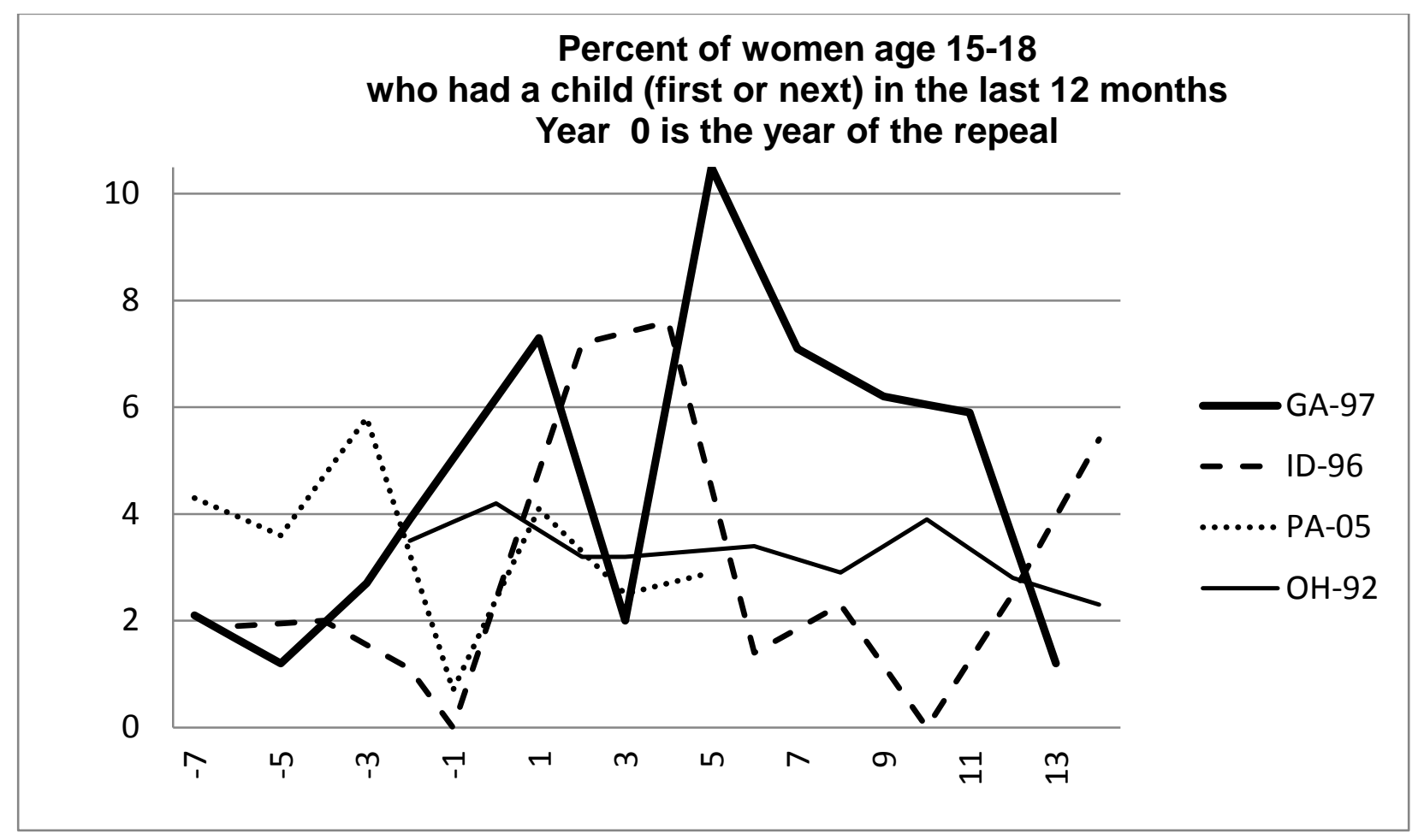


Table 1. Sample means by state's CLM status.

\begin{tabular}{|l|cc|cc|cc|}
\hline & \multicolumn{2}{|c|}{ Age 15-18 } & \multicolumn{2}{c|}{ Age 19-21 } & \multicolumn{3}{c|}{ Age 21-25 } \\
& non-CLM & CLM & non-CLM & CLM & non-CLM & CLM \\
\hline Ever had a child & 5.6 & 6.3 & 21.5 & 26.3 & 39.2 & 42.4 \\
Had a child in the past 12 months & 3.7 & 4.2 & 8.2 & 10.7 & 10.3 & 11.6 \\
Had first child in the past 12 months & 2.2 & 2.7 & 5.4 & 6.2 & 4.7 & 5.0 \\
Currently married & 1.2 & 1.8 & 10.6 & 14.8 & 29.8 & 36.2 \\
Ever married & 2.1 & 2.8 & 12.4 & 17.1 & 35.2 & 42.9 \\
African American & 16.1 & 16.3 & 15.8 & 15.1 & 15.4 & 13.5 \\
Hispanic & 13.8 & 18.7 & 13.5 & 18.1 & 14.5 & 18.8 \\
Asian & 4.0 & 1.9 & 4.2 & 1.8 & 5.0 & 2.6 \\
Other & 1.5 & 1.7 & 1.2 & 1.0 & 1.3 & 1.0 \\
Central city & 26.4 & 27.1 & 29.5 & 30.0 & 33.3 & 33.9 \\
Outside central city & 47.9 & 42.7 & 46.1 & 40.9 & 42.9 & 38.0 \\
Education: no high school & 85.3 & 86.5 & 14.2 & 15.6 & 11.8 & 11.6 \\
Education: some college & 4.6 & 3.2 & 53.2 & 50.5 & 35.9 & 36.7 \\
Education: college & & & 1.8 & 1.3 & 22.6 & 20.7 \\
Education: graduate & & & & & 2.1 & 2.0 \\
Highest educ in family: No high school & 9.0 & 10.9 & & & & \\
Highest educ in family: College & 19.2 & 17.6 & & & & \\
Highest educ in family: Graduate & 12.6 & 11.0 & & & & \\
\hline Observations & 31,759 & 10,347 & 21,761 & 7,163 & 29,334 & 9,709 \\
\hline
\end{tabular}

Notes. Individual characteristics are from June CPS 1990-2010. Means in Panel A are weighted using survey weights, means in Panel B are unweighted. 
Table 2. Means of state-level characteristics.

\begin{tabular}{|c|c|c|c|}
\hline Variable & Source & $\begin{array}{l}\text { non- } \\
\text { CLM }\end{array}$ & CLM \\
\hline Unemployment rate & BLS http://www.bls.gov/data/ & 5.6 & 5.4 \\
\hline $\begin{array}{l}\text { Median household } \\
\text { income in } 2010 \$\end{array}$ & $\begin{array}{l}\text { Table H-8 at } \\
\text { http://www.census.gov/hhes/www/income/data/historical/household/. }\end{array}$ & 50,372 & 48,648 \\
\hline Welfare benefits & $\begin{array}{l}\text { Maximum TANF+SNAP benefits for a family of two, in } 2010 \text { dollars } \\
\text { obtained from the University of Kentucky Center for Poverty Research } \\
\text { http://www.ukcpr.org/AvailableData.aspx }\end{array}$ & 738 & 697 \\
\hline Sex ratio & \multirow{3}{*}{$\begin{array}{l}\text { Calculated from Census state population data by age found at } \\
\text { http://www.census.gov/popest/data/intercensal/state/state2010.html and } \\
\text { https://www.census.gov/popest/data/state/asrh/2012/SC-EST2012- } \\
\text { ALLDATA6.html }\end{array}$} & 1.06 & 1.05 \\
\hline Share of black population & & 0.114 & 0.112 \\
\hline $\begin{array}{l}\text { Share of Hispanic } \\
\text { population }\end{array}$ & & 0.077 & 0.075 \\
\hline $\begin{array}{l}\text { Share of adults age } 25+ \\
\text { with college degree }\end{array}$ & Census: http://www.census.gov/hhes/socdemo/education/ & 24.2 & 23.9 \\
\hline Observations & & 937 & 338 \\
\hline
\end{tabular}

Note: Sex ratios are calculated from Census state population estimates by dividing the number of men in each 5year age group by the number of women who are 2 years younger. For example, in order to get a sex ratio for women aged 18-22, we divide the number of men aged 20-24 by the number of women aged 18-22. Sex ratios are calculated separately for white and black population and for the total population. 'Other race' is assigned sex ratios for total population. 
Table 3. Probit marginal effects of CLM on the probability that a woman age 15-18 had her first child (Panel A) or any child (Panel B) in the last 12 months.

\begin{tabular}{|c|c|c|c|c|c|c|c|}
\hline & \multicolumn{5}{|c|}{ All women } & \multicolumn{2}{|c|}{4 transition states } \\
\hline & 1 & 2 & 3 & 4 & 5 & 6 & 7 \\
\hline \multicolumn{8}{|c|}{ Panel A. Probability that a woman age 15-18 had her first child in last 12 months } \\
\hline CLM & $\begin{array}{c}-0.011 \\
{[0.003]^{* * *}}\end{array}$ & $\begin{array}{c}-0.015 \\
{[0.004]^{* * *}}\end{array}$ & $\begin{array}{c}-0.005 \\
{[0.007]}\end{array}$ & $\begin{array}{c}-0.003 \\
{[0.007]}\end{array}$ & $\begin{array}{c}-0.004 \\
{[0.014]}\end{array}$ & $\begin{array}{c}-0.013 \\
{[0.004]^{* * *}}\end{array}$ & $\begin{array}{c}0.015 \\
{[0.015]}\end{array}$ \\
\hline 3-4 years before repeal & & & $\begin{array}{c}-0.011 \\
{[0.003]^{* * *}}\end{array}$ & $\begin{array}{c}-0.01 \\
{[0.004]^{* *}}\end{array}$ & $\begin{array}{c}-0.01 \\
{[0.005]^{* *}}\end{array}$ & & $\begin{array}{c}-0.016 \\
{[0.003]^{* * *}}\end{array}$ \\
\hline 1-2 years before repeal & & & $\begin{array}{c}-0.007 \\
{[0.004]^{*}}\end{array}$ & $\begin{array}{c}-0.007 \\
{[0.004]}\end{array}$ & $\begin{array}{c}-0.007 \\
{[0.005]}\end{array}$ & & $\begin{array}{c}-0.012 \\
{[0.002]^{* * *}}\end{array}$ \\
\hline 1-2 years after repeal & & & $\begin{array}{c}-0.002 \\
{[0.003]}\end{array}$ & $\begin{array}{c}-0.003 \\
{[0.003]}\end{array}$ & $\begin{array}{c}-0.004 \\
{[0.004]}\end{array}$ & & $\begin{array}{c}-0.008 \\
{[0.002]^{* * *}}\end{array}$ \\
\hline CLM * Black & & & & -0.01 & -0.01 & & -0.009 \\
\hline CLM * Hispanic & & & & $\begin{array}{c}0 \\
{[0.004]}\end{array}$ & $\begin{array}{c}0 \\
{[0.004]}\end{array}$ & & {$[0.000]$} \\
\hline Observations & 40,811 & 40,811 & 40,811 & 40,811 & 40,811 & 4,075 & 4,019 \\
\hline \multicolumn{8}{|c|}{ Panel B. Probability that a woman age 15-18 had a child in last 12 months } \\
\hline CLM & $\begin{array}{c}-0.012 \\
{[0.005]^{* *}}\end{array}$ & $\begin{array}{c}-0.021 \\
{[0.008]^{* *}}\end{array}$ & $\begin{array}{c}-0.008 \\
{[0.008]}\end{array}$ & $\begin{array}{c}-0.005 \\
{[0.009]}\end{array}$ & $\begin{array}{c}-0.019 \\
{[0.014]}\end{array}$ & $\begin{array}{c}-0.016 \\
{[0.006]^{* * *}}\end{array}$ & $\begin{array}{c}0.004 \\
{[0.017]}\end{array}$ \\
\hline 3-4 years before repeal & & & $\begin{array}{c}-0.001 \\
{[0.010]}\end{array}$ & $\begin{array}{c}-0.001 \\
{[0.010]}\end{array}$ & $\begin{array}{c}0.014 \\
{[0.010]}\end{array}$ & & $\begin{array}{c}-0.011 \\
{[0.010]}\end{array}$ \\
\hline 1-2 years before repeal & & & $\begin{array}{c}-0.025 \\
{[0.003]^{* * *}}\end{array}$ & $\begin{array}{c}-0.024 \\
{[0.003]^{* * *}}\end{array}$ & $\begin{array}{c}-0.02 \\
{[0.004]^{* * *}}\end{array}$ & & $\begin{array}{c}-0.025 \\
{[0.003]^{* * *}}\end{array}$ \\
\hline 1-2 years after repeal & & & $\begin{array}{c}0.004 \\
{[0.005]}\end{array}$ & $\begin{array}{c}0.003 \\
{[0.005]}\end{array}$ & $\begin{array}{c}0.003 \\
{[0.008]}\end{array}$ & & $\begin{array}{c}-0.004 \\
{[0.007]}\end{array}$ \\
\hline CLM * Black & & & & -0.015 & -0.015 & & -0.01 \\
\hline & & & & {$[0.005]^{* * *}$} & {$[0.005]^{* * *}$} & & {$[0.010]$} \\
\hline CLM * Hispanic & & & & $\begin{array}{l}-0.004 \\
{[0.006]}\end{array}$ & $\begin{array}{l}-0.003 \\
{[0.006]}\end{array}$ & & $\begin{array}{l}-0.016 \\
{[0.014]}\end{array}$ \\
\hline Observations & 42,106 & 42,106 & 42,106 & 42,106 & 42,106 & 4,417 & 4,417 \\
\hline $\begin{array}{l}\text { State characteristics } \\
\text { Year, state fixed } \\
\text { effects } \\
\text { State-specific trends }\end{array}$ & $\mathrm{X}$ & $X$ & $\mathrm{X}$ & $\mathrm{X}$ & $\begin{array}{l}X \\
X\end{array}$ & $\mathrm{X}$ & $\mathrm{X}$ \\
\hline
\end{tabular}

Notes: All regressions include demographic controls. Robust standard errors in brackets. Standard errors are clustered by state-year. * * significant at $10 \%$; ** significant at $5 \%$; *** significant at $1 \%$. Sample: women age $15-$ 18 from June CPS 1990-2010; women who had a child prior to 12 month before the survey are removed in Panel B because they cannot become first time mothers; this does not alter results. Only 589 girls in this age group are married; excluding them does not alter results. 
Table 4. Probit marginal effects of CLM on the probability that a woman had first, any child (first or any) in last 12 months.

\begin{tabular}{|l|c|c|cc|cc|}
\hline & \multicolumn{2}{|c|}{ Age 15-18 } & \multicolumn{2}{c|}{ Age 19-21 } & \multicolumn{2}{c|}{ Age 22-25 } \\
\hline \multicolumn{1}{|l|}{ Panel A. Probability that a woman had her first child in last 12 months } \\
\hline CLM & -0.003 & -0.004 & 0 & 0.03 & 0 & 0.065 \\
& {$[0.007]$} & {$[0.014]$} & {$[0.016]$} & {$[0.036]$} & {$[0.021]$} & {$[0.071]$} \\
3-4 years before repeal & -0.01 & -0.01 & 0.023 & -0.005 & 0.023 & 0.002 \\
& {$[0.004]^{* *}$} & {$[0.005]^{* *}$} & {$[0.027]$} & {$[0.016]$} & {$[0.026]$} & {$[0.032]$} \\
1-2 years before repeal & -0.007 & -0.007 & -0.016 & -0.027 & 0.034 & -0.008 \\
& {$[0.004]$} & {$[0.005]$} & {$[0.008]^{*}$} & {$[0.010]^{* * *}$} & {$[0.027]$} & {$[0.031]$} \\
1-2 years after repeal & -0.003 & -0.004 & 0.017 & 0.014 & -0.015 & -0.006 \\
& {$[0.003]$} & {$[0.004]$} & {$[0.017]$} & {$[0.017]$} & {$[0.011]$} & {$[0.014]$} \\
CLM * Black & -0.01 & -0.01 & 0.01 & 0.008 & 0.001 & 0.003 \\
& {$[0.002]^{* * *}$} & {$[0.002]^{* * *}$} & {$[0.015]$} & {$[0.014]$} & {$[0.018]$} & {$[0.019]$} \\
CLM * Hispanic & 0 & 0 & 0.016 & 0.016 & -0.012 & -0.011 \\
& {$[0.004]$} & {$[0.004]$} & {$[0.015]$} & {$[0.015]$} & {$[0.010]$} & {$[0.010]$} \\
\hline Observations & 40,811 & 40,811 & 24,154 & 24,154 & 25,293 & 25,293 \\
\hline Panel B. Probability that a woman had a child in last 12 months \\
\hline CLM & -0.005 & -0.019 & -0.008 & -0.049 & -0.006 & 0.19 \\
& {$[0.009]$} & {$[0.014]$} & {$[0.016]$} & {$[0.018]^{* * *}$} & {$[0.022]$} & {$[0.055]^{* * *}$} \\
3-4 yeard before repeal & -0.001 & 0.014 & 0.015 & 0.03 & 0.017 & -0.047 \\
& {$[0.010]$} & {$[0.010]$} & {$[0.027]$} & {$[0.035]$} & {$[0.023]$} & {$[0.008]^{* * *}$} \\
1-2 years before repeal & -0.024 & -0.02 & 0.044 & 0.089 & 0.058 & -0.038 \\
& {$[0.003]^{* * *}$} & {$[0.004]^{* * *}$} & {$[0.017]^{* *}$} & {$[0.035]^{* * *}$} & {$[0.024]^{* *}$} & {$[0.013]^{* * *}$} \\
1-2 years after repeal & 0.003 & 0.003 & 0.028 & 0.008 & 0 & 0.035 \\
& {$[0.005]$} & {$[0.008]$} & {$[0.018]$} & {$[0.016]$} & {$[0.016]$} & {$[0.020]^{*}$} \\
CLM * Black & -0.015 & -0.015 & 0.034 & 0.033 & -0.001 & 0 \\
& {$[0.005]^{* * *}$} & {$[0.005]^{* * *}$} & {$[0.018]^{*}$} & {$[0.017]^{*}$} & {$[0.015]$} & {$[0.015]$} \\
CLM * Hispanic & -0.004 & -0.003 & 0.027 & 0.026 & 0.002 & 0.001 \\
& {$[0.006]$} & {$[0.006]$} & {$[0.018]$} & {$[0.018]$} & {$[0.010]$} & {$[0.010]$} \\
\hline Observations & 42,106 & 42,106 & 28,924 & 28,924 & 39,043 & 39,043 \\
\hline
\end{tabular}

Notes: All regressions include demographic controls, as well as either state and year effects or state-specific trends. Robust standard errors in brackets. * significant at $10 \%$; ** significant at $5 \%$; *** significant at $1 \%$. Sample: women age 15-18 from June CPS 1990-2010. 
Table 5. Robustness check: OLS estimates of linear probability models with data aggregated by state/year.

\begin{tabular}{|c|c|c|c|c|c|c|c|c|}
\hline & \multicolumn{4}{|c|}{ Age 15-18 } & \multicolumn{4}{|c|}{ Age 19-21 } \\
\hline & 1 & 2 & 3 & 4 & 5 & 6 & 7 & 8 \\
\hline \multicolumn{9}{|c|}{ Panel A. Probability that a woman had first child } \\
\hline CLM & -0.008 & -0.017 & -0.007 & -0.016 & 0.004 & -0.014 & 0.017 & 0.026 \\
\hline 3-4 years before repeal & & & $\begin{array}{c}{[0.013]} \\
-0.007 \\
{[0.014]}\end{array}$ & $\begin{array}{c}{[0.024]} \\
-0.005 \\
{[0.017]}\end{array}$ & & & $\begin{array}{c}{[0.023]} \\
-0.002 \\
{[0.027]}\end{array}$ & $\begin{array}{c}{[0.046]} \\
-0.013 \\
{[0.033]}\end{array}$ \\
\hline \multirow[t]{2}{*}{ 1-2 years before repeal } & & & 0.003 & 0.005 & & & -0.071 & -0.089 \\
\hline & & & [0.016] & [0.021] & & & {$[0.032]^{* *}$} & {$[0.041]^{* *}$} \\
\hline \multirow[t]{2}{*}{$1-2$ years after repeal } & & & 0.007 & 0.009 & & & -0.008 & -0.006 \\
\hline & & & [0.013] & [0.016] & & & {$[0.026]$} & {$[0.031]$} \\
\hline \multirow[t]{2}{*}{ CLM * Black } & -0.055 & -0.026 & -0.037 & 0.001 & 0.031 & 0.051 & 0.023 & 0.041 \\
\hline & {$[0.033]^{*}$} & [0.042] & [0.033] & [0.043] & {$[0.065]$} & {$[0.075]$} & {$[0.065]$} & {$[0.076]$} \\
\hline \multirow[t]{2}{*}{ CLM * Hispanic } & 0.053 & 0.109 & 0.011 & 0.091 & 0.234 & 0.326 & 0.213 & 0.372 \\
\hline & [0.057] & [0.067] & {$[0.051]$} & {$[0.067]$} & {$[0.111]^{* *}$} & {$[0.123]^{* * *}$} & {$[0.096]^{* *}$} & {$[0.113]^{* * *}$} \\
\hline R-squared & 0.14 & 0.21 & 0.17 & 0.25 & 0.17 & 0.24 & 0.21 & 0.28 \\
\hline State characteristics & $\mathrm{X}$ & $\mathrm{X}$ & $\mathrm{X}$ & $\mathrm{X}$ & $\mathrm{X}$ & $\mathrm{X}$ & $\mathrm{X}$ & $\mathrm{X}$ \\
\hline Year, state fixed effects & $\mathrm{X}$ & & $\mathrm{X}$ & & $\mathrm{X}$ & & $\mathrm{X}$ & \\
\hline State-specific trends & & $\mathrm{X}$ & & $\mathrm{X}$ & & $\mathrm{X}$ & & $\mathrm{X}$ \\
\hline \multicolumn{9}{|c|}{ Panel B. Probability that a woman had a child } \\
\hline \multirow[t]{2}{*}{ CLM } & -0.012 & -0.016 & -0.003 & -0.017 & 0.021 & -0.001 & 0.002 & -0.016 \\
\hline & [0.009] & [0.015] & [0.014] & [0.027] & [0.017] & [0.027] & [0.025] & [0.048] \\
\hline \multirow[t]{2}{*}{ 3-4 years before repeal } & & & -0.003 & -0.002 & & & -0.002 & -0.002 \\
\hline & & & [0.015] & [0.019] & & & [0.028] & [0.034] \\
\hline \multirow[t]{2}{*}{ 1-2 years before repeal } & & & -0.006 & -0.005 & & & -0.029 & -0.026 \\
\hline & & & [0.018] & [0.023] & & & [0.033] & [0.041] \\
\hline \multirow[t]{2}{*}{ 1-2 years after repeal } & & & 0.011 & 0.012 & & & 0.002 & -0.009 \\
\hline & & & [0.015] & [0.018] & & & [0.027] & [0.032] \\
\hline \multirow[t]{2}{*}{ CLM * Black } & -0.056 & -0.011 & -0.033 & 0.028 & 0.078 & 0.049 & 0.081 & 0.063 \\
\hline & [0.038] & {$[0.050]$} & [0.038] & {$[0.050]$} & {$[0.064]$} & {$[0.075]$} & {$[0.065]$} & {$[0.075]$} \\
\hline \multirow[t]{2}{*}{ CLM * Hispanic } & 0.03 & 0.069 & 0.023 & 0.105 & 0.103 & 0.137 & 0.14 & 0.224 \\
\hline & [0.065] & {$[0.078]$} & {$[0.058]$} & {$[0.076]$} & [0.113] & [0.124] & [0.095] & {$[0.113]^{* *}$} \\
\hline R-square & 0.2 & 0.26 & 0.21 & 0.26 & 0.2 & 0.3 & 0.21 & 0.3 \\
\hline State characteristics & $\mathrm{X}$ & $\mathrm{X}$ & $\mathrm{X}$ & $\mathrm{X}$ & $\mathrm{X}$ & $\mathrm{X}$ & $\mathrm{X}$ & $\mathrm{X}$ \\
\hline Year, state fixed effects & $\mathrm{X}$ & & $\mathrm{X}$ & & $\mathrm{X}$ & & $\mathrm{X}$ & \\
\hline State-specific trends & & $\mathrm{X}$ & & $\mathrm{X}$ & & $\mathrm{X}$ & & $\mathrm{X}$ \\
\hline Observations & 561 & 561 & 561 & 561 & 561 & 561 & 561 & 561 \\
\hline
\end{tabular}

Notes: To obtain these estimates, we first regress data on individual-level controls and collect residuals. Then we compute average residuals by year and state, and regress them on state characteristics and year and state fixed effect or year fixed effects and state time trends. 
Appendix. Marginal effects from probit regressions for the probability that the adolescent had her first child in the last 12 months. June CPS individual-level data 1990-2010.

\begin{tabular}{|c|c|c|c|c|}
\hline & \multicolumn{2}{|c|}{ Age $15-18$} & \multicolumn{2}{|c|}{ Age $19-21$} \\
\hline & 1 & 2 & 3 & 4 \\
\hline \multirow[t]{2}{*}{ CLM } & -0.003 & -0.004 & 0 & 0.03 \\
\hline & [0.007] & [0.014] & [0.016] & [0.036] \\
\hline \multirow[t]{2}{*}{ 3-4 years before repeal } & -0.01 & -0.01 & 0.023 & -0.005 \\
\hline & {$[0.004]^{* *}$} & {$[0.005]^{* *}$} & {$[0.027]$} & {$[0.016]$} \\
\hline \multirow[t]{2}{*}{ 1-2 years before repeal } & -0.007 & -0.007 & -0.016 & -0.027 \\
\hline & {$[0.004]$} & {$[0.005]$} & {$[0.008]^{*}$} & {$[0.010]^{* * *}$} \\
\hline \multirow[t]{2}{*}{ 1-2 years after repeal } & -0.003 & -0.004 & 0.017 & 0.014 \\
\hline & {$[0.003]$} & {$[0.004]$} & {$[0.017]$} & {$[0.017]$} \\
\hline \multirow[t]{2}{*}{ CLM*Black } & -0.01 & -0.01 & 0.01 & 0.008 \\
\hline & {$[0.002] * * *$} & {$[0.002]^{* * *}$} & [0.015] & [0.014] \\
\hline \multirow[t]{2}{*}{ CLM*Hispanic } & 0 & 0 & 0.016 & 0.016 \\
\hline & [0.004] & [0.004] & [0.015] & [0.015] \\
\hline \multirow[t]{2}{*}{ Black } & 0.014 & 0.014 & 0.039 & 0.038 \\
\hline & {$[0.004] * * *$} & {$[0.004]^{* * *}$} & {$[0.009]^{* * *}$} & {$[0.009]^{* * *}$} \\
\hline \multirow[t]{2}{*}{ Hispanic } & 0.012 & 0.011 & 0.033 & 0.034 \\
\hline & {$[0.004] * * *$} & {$[0.004] * * *$} & {$[0.011]^{* * *}$} & {$[0.011]^{* * *}$} \\
\hline \multirow[t]{2}{*}{ Asian } & 0.002 & 0.003 & -0.009 & -0.01 \\
\hline & {$[0.004]$} & {$[0.004]$} & {$[0.011]$} & {$[0.011]$} \\
\hline \multirow[t]{2}{*}{ Other race } & 0.006 & 0.006 & 0.044 & 0.046 \\
\hline & {$[0.006]$} & {$[0.006]$} & {$[0.021]^{* *}$} & {$[0.021]^{* *}$} \\
\hline \multirow[t]{2}{*}{ Metropolitan residence: central city } & 0.003 & 0.003 & -0.013 & -0.012 \\
\hline & {$[0.003]$} & {$[0.003]$} & {$[0.005]^{* *}$} & {$[0.005]^{* *}$} \\
\hline \multirow[t]{2}{*}{ Residence outside central city } & 0.002 & 0.001 & -0.007 & -0.007 \\
\hline & [0.002] & {$[0.002]$} & [0.005] & [0.005] \\
\hline \multirow[t]{2}{*}{ Education: no high school } & -0.008 & -0.007 & 0.011 & 0.01 \\
\hline & {$[0.003]^{* * *}$} & {$[0.002]^{* * *}$} & {$[0.006]^{*}$} & {$[0.006]^{*}$} \\
\hline \multirow[t]{2}{*}{ Education: some college } & -0.008 & -0.008 & -0.083 & -0.082 \\
\hline & {$[0.002] * * *$} & {$[0.002]^{* * *}$} & {$[0.005]^{* * *}$} & {$[0.005]^{* * *}$} \\
\hline \multirow[t]{2}{*}{ Education: college } & 0.025 & 0.024 & -0.05 & -0.05 \\
\hline & {$[0.004] * * *$} & {$[0.004] * * *$} & {$[0.002]^{* * *}$} & {$[0.002]^{* * *}$} \\
\hline \multirow[t]{2}{*}{ Max educ in family: no high school } & -0.01 & -0.01 & & \\
\hline & {$[0.002]^{* * *}$} & {$[0.002]^{* * *}$} & & \\
\hline \multirow[t]{2}{*}{ Max educ in family: college } & -0.011 & -0.01 & & \\
\hline & {$[0.002]^{* * *}$} & {$[0.002]^{* * *}$} & & \\
\hline Max educ in family: graduate degree & 0.001 & 0.003 & & \\
\hline & {$[0.020]$} & {$[0.019]$} & & \\
\hline Sex ratio, race-specific & -0.001 & -0.002 & 0.003 & -0.004 \\
\hline & [0.001] & [0.001] & [0.027] & [0.027] \\
\hline Unemployment rate & 0.019 & 0.022 & 0.001 & 0.004 \\
\hline & {$[0.009]^{* *}$} & {$[0.012]^{*}$} & {$[0.002]$} & {$[0.003]$} \\
\hline Log of max AFDC benefits, family of 2 & 0.001 & -0.004 & -0.013 & -0.012 \\
\hline & {$[0.019]$} & {$[0.018]$} & {$[0.022]$} & {$[0.033]$} \\
\hline Log of median state income & 0 & 0.001 & 0.063 & 0.056 \\
\hline & {$[0.001]$} & {$[0.001]$} & {$[0.044]$} & {$[0.043]$} \\
\hline Share of adults with college degree & -0.065 & -0.316 & -0.001 & -0.003 \\
\hline & {$[0.138]$} & {$[0.494]$} & {$[0.002]$} & {$[0.002]$} \\
\hline Share of black population in state & 0.054 & 0.107 & -0.152 & -3.449 \\
\hline & {$[0.030]^{*}$} & {$[0.041]^{* * *}$} & [0.383] & {$[1.388]^{* *}$} \\
\hline Share of Hispanic population in state & 0 & 0.001 & 0.051 & 0.094 \\
\hline & {$[0.001]$} & {$[0.001]$} & {$[0.073]$} & {$[0.096]$} \\
\hline Year and state fixed effects & $\mathrm{X}$ & & $\mathrm{X}$ & \\
\hline State-specific time trends & & $\mathrm{X}$ & & $\mathrm{X}$ \\
\hline Observations & 40,811 & 40,811 & 24154 & 24154 \\
\hline
\end{tabular}

Also included in regression: dummies for age. 